University of Wollongong

Research Online

Faculty of Law, Humanities and the Arts Papers (Archive)

$1-1-2014$

Four scholars speak to navigating the complexities of naming in Indigenous studies

Bronwyn Carlson

University of Wollongong, bcarlson@uow.edu.au

J Berglund

Northern Arizona University

Michelle Harris

Northern Arizona University

Evan S. Te Ahu Poata-Smith

University of Wollongong, evanps@uow.edu.au

Follow this and additional works at: https://ro.uow.edu.au/lhapapers

Part of the Arts and Humanities Commons, and the Law Commons

Research Online is the open access institutional repository for the University of Wollongong. For further information contact the UOW Library: research-pubs@uow.edu.au 


\title{
Four scholars speak to navigating the complexities of naming in Indigenous studies
}

\begin{abstract}
Universities in Australia are expanding their Aboriginal and Torres Strait Islander Studies programs to include Indigenous populations from around the globe. This is also the case for the Indigenous Studies Unit at the University of Wollongong (UOW). Although systems of nomenclature in Indigenous Studies seek to be respectful of difference, the politics of naming in the global context raises some complexities worthy of discussion. In this article, four scholars discuss the politics of naming in relation to teaching a joint Indigenous Studies subject at the UOW and Northern Arizona University.
\end{abstract}

\section{Keywords}

navigating, speak, naming, scholars, four, complexities, indigenous, studies

\section{Disciplines}

Arts and Humanities | Law

\section{Publication Details}

Carlson, B., Berglund, J., Harris, M. \& Poata-Smith, E. S. (2014). Four scholars speak to navigating the complexities of naming in Indigenous studies. Australian Journal of Indigenous Education, 43 (1), 58-72. 


\section{The Australian Journal of Indigenous Education}

http://journals.cambridge.org/JIE

Additional services for The Australian Journal of Indigenous Education:

Email alerts: Click here

Subscriptions: Click here

Commercial reprints: Click here

Terms of use : $\underline{\text { Click here }}$

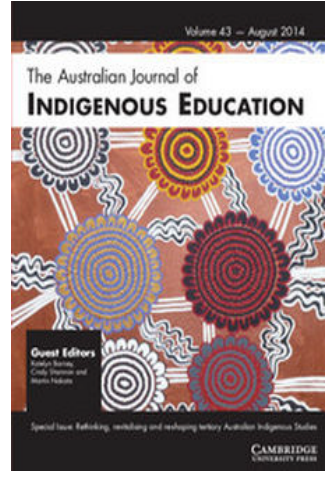

\section{Four Scholars Speak to Navigating the Complexities of Naming in Indigenous Studies}

Bronwyn Carlson, Jeff Berglund, Michelle Harris and Evan Te Ahu Poata-Smith

The Australian Journal of Indigenous Education / Volume 43 / Special Issue 01 / August 2014, pp 58 - 72

DOI: 10.1017/jie.2014.8, Published online: 15 August 2014

Link to this article: http://journals.cambridge.org/abstract_S1326011114000088

How to cite this article:

Bronwyn Carlson, Jeff Berglund, Michelle Harris and Evan Te Ahu Poata-Smith (2014). Four Scholars Speak to Navigating the Complexities of Naming in Indigenous Studies. The Australian Journal of Indigenous Education, 43, pp 58-72 doi:10.1017/jie.2014.8

Request Permissions : $\underline{\text { Click here }}$ 


\title{
Four Scholars Speak to Navigating the Complexities of Naming in Indigenous Studies
}

\author{
Bronwyn Carlson, ${ }^{1}$ Jeff Berglund, ${ }^{2}$ Michelle Harris ${ }^{3}$ and Evan Te Ahu Poata-Smith ${ }^{1}$ \\ 1 Indigenous Studies Unit, Faculty of Law, Humanities and the Arts, University of Wollongong, Wollongong, New South Wales, \\ Australia \\ 2 Ethnic Studies and Applied Indigenous Studies, Northern Arizona University, Flagstaff, Arizona, USA \\ ${ }^{3}$ Department of Sociology and Social Work, Northern Arizona University, Flagstaff, Arizona, USA
}

\begin{abstract}
Universities in Australia are expanding their Aboriginal and Torres Strait Islander Studies programs to include Indigenous populations from around the globe. This is also the case for the Indigenous Studies Unit at the University of Wollongong (UOW). Although systems of nomenclature in Indigenous Studies seek to be respectful of difference, the politics of naming in the global context raises some complexities worthy of discussion. In this article, four scholars discuss the politics of naming in relation to teaching a joint Indigenous Studies subject at the UOW and Northern Arizona University.
\end{abstract}

Keywords: Indigeneity, language use, terminology, nomenclature

\section{Background}

In 2011, the Aboriginal Studies program at the University of Wollongong (UOW) was renamed to Indigenous Studies in a move to expand its focus to include Indigenous populations from around the globe. The new global focus led to the development of new curriculum and the incorporation of global Indigenous perspectives into some existing content. A new first-year undergraduate subject was developed that focused on Indigenous knowledge globally, and the Indigenous Studies team expanded to include a Māori scholar. Although the teaching team has always included non-Aboriginal members, the label 'nonAboriginal' now included an Indigenous person from another country. Building on the expansion of the program, members of the Indigenous Studies team established The Forum for Indigenous Research Excellence (FIRE). FIRE is a global research group whose members are based anywhere in the world; each maintains an active involvement and/or interest in research activities in an Indigenous context. Resources in regard to terminology and Indigenous peoples can also be found on the FIRE website (http://ha.uow.edu.au/hsi/research/fire/index.html).

Members of the Indigenous Studies team at UOW have been working with scholars from Northern Arizona University (NAU) for the past 5 years. This relationship includes both teaching and research projects that have focused on global Indigenous identity, and has resulted in a range of outcomes, including an edited volume, The Politics of Identity: Emerging Indigeneity (Harris,
Carlson, \& Poata-Smith, 2013) and a collaborative curriculum project. In 2013, scholars from UOW spent time at NAU collaborating on the development of a secondyear undergraduate Indigenous Studies subject, 'Indigenous Identities in a Global Context'. The aim of the subject is to explore critical issues in contemporary global Indigeneity, and it will be taught at both UOW and NAU. The group was also successful in their application for an International Links Grant (UOW) to reconvene the group in 2014. This will allow the development of curriculum resources to support the delivery of the subject. While the Indigenous Studies program at UOW is firmly anchored in the experiences of Aboriginal and Torres Strait Islander peoples, we believe that including global Indigenous perspectives, content and epistemologies will enrich our curriculum. With the adoption of the Declaration on the Rights of Indigenous Peoples led by the United Nations General Assembly in 2007, and the establishment of The United Nations Permanent Forum on Indigenous Issues, students need to be better prepared to engage with the ongoing global issues related to Indigenous economic and social development, cultures, the environment, education, health, identities, and human rights.

ADDRESS FOR CORRESPONDENCE: Bronwyn Carlson, Indigenous Studies Unit, Faculty of Law, Humanities and the Arts, University of Wollongong, Wollongong NSW 2522, Australia Email: bcarlson@uow.edu.au. 


\section{Introduction}

Names are more than just a title or designation; they can and do convey powerful messages through the meanings attached to them. Some commonly used terms affiliated with Indigenous peoples bear the troubling legacy of colonialism. Other terms have existed from time immemorial. And while the meanings of all names are unstable and often ambiguous, they convey powerful imagery and form the cornerstone of our identities. Ethnic labels, whether they emerge from within or outside of groups, also serve the function of establishing particular populations as different from one another. In subtle ways, therefore, labelling communities suggests an alliance in terms of shared interests, a sense of cooperation, and ties to a common tradition or heritage. A sense of identity is built by contrasting one's self with others: this can occur at the individual or group level. Contrastive roles help to build a sense of self and cement group loyalty.

Language is not a neutral or unproblematic medium. Indeed, language embodies the contested social norms and values that are embedded in the society in which we live. As Ransome (2010) points out: 'The language social actors use during their internal conversations is socially constructed and as such it uses ideas and concepts that have been communally produced within society' (p. 211). For this reason, it is important to focus on how language can be used to structure and limit our ideas and understandings of the world around us.

Scholars have long highlighted how discourses of class, gender, sexuality, 'race' and empire pathologise, marginalise and subjugate whole categories of humanity. Feminist scholars, for instance, have highlighted the way language has tended to encode male worldviews, by helping to subordinate women or to render them invisible, or by taking male experiences as the norm (Cameron, 1985; Haslanger, 1995; MacKinnon, 1989, 1993; Moulton, 1981a, 1981b; Spender, 1985). Analyses of racist discourse in Australia and New Zealand reveal two consistent attributes of language used by respondents: (1) it is organised rhetorically to avoid the attribution of racism; and (2) it undermines and deflects Indigenous demands for sovereignty, justice, and equity (Augoustinos, Tuffin, \& Rapley, 1999; Augoustinos, Tuffin, \& Sale, 1999; Wetherell \& Potter, 1992).

The way language may both reflect and (re)produce unequal relations of power has a particular resonance for those interested in Indigenous Studies. How has language (such as the choice of terminology) been used historically to limit understandings of Indigenous histories, knowledges, experiences and social realities? How is language used today to name, categorise and marginalise Indigenous communities? It is important to remember that discourses are emergent products of human consciousness: they are ways of talking about and interpreting the world. They are, however, inert, and by definition cannot possess agency and the capacity to act in the world. It is important to emphasise, therefore, that it is not discourses that impose particular interpretations of the world on individuals and groups, but social actors. The tensions between actors and the particular discourses they articulate are concretely negotiated in particular historical settings.

Our goal in this article is to consider the challenges of conveying the nuances and complexities of naming, and more specifically nomenclature, when teaching subjects that have a global Indigenous focus. As being Indigenous is increasingly acquiring a more globalised focus, terms such 'indigenous' and 'indigeneity' are taking precedence over other more localised identifiers (Merlan, 2009), as discussed throughout by each author. As Merlan (2009) notes, 'indigeneity' has come to presuppose a sphere of commonality among those who form a world collectivity of 'indigenous peoples' (p. 303). While 'indigeneity' has different values in different contexts, it also provides a basis for participation in global institutions, such as the United Nations Permanent Forum on Indigenous Issues. There is, arguably, a sense of solidarity among Indigenous peoples globally, particularly when the history of colonisation and marginalisation is similar.

Although we determined to follow current trends in the wake of the U.N. Declaration, we also understand that local and regional histories need to be recognised and valued. Thus, we asked ourselves, what terminology is appropriate when speaking about multiple groups of Indigenous/Aboriginal/First Nations/Native peoples? And what of the students who will undoubtedly be of varied cultural backgrounds, including Indigenous peoples? How will they respond to the various terms and labels used to refer to them?

As our collaborative group began discussions about the new subject, which is globally Indigenous in scope, it became apparent that there was much to consider in relation to terminology. What terms should we use that would be inclusive and respectful while also acknowledging that what 'being' Indigenous means or entails is different according to local histories, laws and circumstances? We even needed to make decisions about capitalisation. Throughout this article we have followed the convention of capitalising the word 'Indigenous', when it references, broadly, a proper name for a people. This custom is in keeping with usage by the United Nations. While it may be a custom in the Australian context to use capitalised 'Indigenous' to refer to Aboriginal Australians and Torres Strait Islanders, and lower-case 'indigenous' to refer to peoples outside of Australia, we depart from that convention to demonstrate the complications that emerge when doing transglobal comparative work. Moreover, capital ' $\mathrm{I}$ ' in one case versus another assumes a centring norm (in this case, Australia) and we eschew that. Our usage acknowledges the need for a portable, transglobal term that still exists alongside meaningful and contextually 
specific nomenclature germane to local cultures, histories and politics. Co-author Poata-Smith's section below summarises critiques of the globalising usage of the term 'Indigenous'.

Our early discussions only touched on these issues and we are determined to explore these complexities more fully in this article. Early on, we recognised that the multiple valences of the term 'Indian' would need to be probed as its global circulation has perpetuated stereotypes and misunderstandings. Similarly, we recognised that the term 'Native', used with great frequency in the North American context, is incredibly vexed in other contexts, as is the term 'tribe'. We also recognised that the terms 'Alaskan Native' and 'Native Hawaiian' might demand explanation in ways that might parallel distinctions that exist among 'Aboriginal peoples' and 'Torres Strait Islanders'. Similarly, in the Australian context, the antiquated and unfavourable term 'aborigine' deserves discussion as it continues to circulate in historical texts and is satirised in contemporary contexts, including the Australian blockbuster film Bran Nue Dae (2009). In addition to terms such as 'mob' and 'country' and regional terms for cultural language groups, we recognised that the terms 'Whitefella' and 'Blackfella' might present some challenges to students, particularly from the United States, who are familiar with the term 'Black' in non-Indigenous contexts, seeing the word as synonymous with 'African American' or 'African', depending on the situation.

Finally, and despite our common thinking that the United Nations Declaration on the Rights of Indigenous Peoples would be instrumental in establishing confluences and parallels in a subject such as the one we are designing, we recognise that there is resistance to the term 'Indigenous' among some groups. It was out of these varied discussions that we took note of a profound tension that would remain at the centre of any subject on global Indigeneity: while Indigenous people are active in the global context, and while comparisons can be made among Indigenous peoples from different corners of the globe, Indigenous identities are foundationally anchored in the local.

In the following section, four scholars speak of navigating the complexities of racial and ethnic labels in their respective context: Australia, New Zealand, and the United States. What can be gleaned from the discussion that follows is that nomenclature evolves; nomenclature is responsive to local traditions and contemporary needs; nomenclature can be empowering; nomenclature is political; nomenclature is linked to power structures; and nomenclature continues to be used to oppress, diminish and control. In popular and academic arenas, unfavourable terms continue to be used, further shoring up regimes of power. It is our aim to teach our students to interrupt this flow of misinformation and to develop a responsive repertoire of critical dexterity regarding the multiple and varied realities of Indigenous peoples.

\section{Māori}

\section{Evan Poata-Smith}

As a Māori scholar who has taught in Aotearoa/New Zealand, Australia and the United States, I am very conscious of the ongoing controversies associated with the categorisation and naming of Indigenous communities in different global settings. The categories and names that are applied to Indigenous communities are, of course, located within the dominant institutional practices and discourses of particular societies at particular points in space and time. In this sense, the differences in terminology not only reflect the historical, linguistic and political conventions and protocols of particular national settings, but also the specific trajectories of Indigenous struggles against the imposition of colonial categories and names. It is important to recognise that on a global scale, Indigenous people may live in different colonial and Indigenous systems and therefore have '.. different kinds of experience with colonialism and different possibilities for decolonization' (Smith, 1999, p. 70). As such, the names and categories are contested both within Indigenous communities and between them. Contemporary Māori identities, for instance, have been constituted amid a flow of competing discourses about what it means to be a member of iwi, hapū and/or urban Māori communities. Iwi, hapū and whānau are the basic social units of Māori society and are based on descent from common ancestors. The word 'iwi' (which is often mistranslated as 'tribe') refers to the widest of possible descent categories. 'Hapū' constitute narrower descent groups made up of related 'whānau' (extended family groupings). The negotiation and renegotiation of contemporary Māori identities is a contested process in the sense that it involves claiming and resisting identities from within a set of prevailing discourses about the authenticity of particular Indigenous categories (Poata-Smith, 2013).

While Indigenous Studies scholars insist that the historical and contemporary experiences of colonialism by Indigenous individuals and communities are not homogeneous, we confront a number of issues particularly when searching for the vocabulary to identify and describe the common experiences of Indigenous people on a global scale (Coates, 2004). Niezen (2003) makes the point that it is ironic that the use of the singular category 'indigenous people' has become so entrenched as a way of describing the existence of significant human diversity, when, in his view, it is actually predicated on uniformity of experience that is more often than not expressed through mechanisms of law and bureaucracy - the very 'culprits most commonly associated with the steady gains of cultural uniformity' (p. 2).

While there is a risk that such a category may too easily gloss over significant cultural, political and social differences, in my experience Indigenous scholars generally recognise and acknowledge those differences. 
Furthermore, it should be remembered that colonial states have a long history of ignoring and disregarding the significant differences that exist among the Indigenous communities they have subjugated - regardless of how those communities have chosen to categorise themselves.

In Aotearoa/New Zealand there has also been a strong rejection of English terms and linguistic conventions to describe Māori identities, geographical features, and experiences. This has been expressed in the struggles over geographical names of mountains, rivers, place names, and other significant sites that were renamed after British people and places to create a sense of 'home' and proclaim membership of the British Empire (Greenland, 1991; Smith, 1999). Although the legacy of colonialism continues to be embodied - for example, in street names, monuments, architecture, libraries, museum collections and the flows of commodities, images and people - this has emerged as a site of ongoing struggle for Māori.

Much attention has focused on the role of the New Zealand Geographic Board (Ngā Pou Taunaha o Aotearoa), which is the statutory body that assigns official names to New Zealand places and features (such as mountains and rivers, as well as settlements and localities). Since 2008, there has been a legislative requirement that the Board collect original Māori place names, seek advice from Te Taura Whiri i te Reo Māori (Māori Language Commission) on correct orthography of Maori names, and encourage the use of original Māori place names on official maps and charts (New Zealand Geographic Board Nga Pou Taunaha o Aotearoa Act 2008).

Demands for the restoration of original Māori place names are also often an integral part of the settlements negotiated between individual tribes and the Crown under the Treaty Waitangi. For instance, when the South Island iwi, Ngāi Tahu, successfully negotiated the Ngāi Tahu settlement with the government of New Zealand, 96 place names were specified for alterations. The majority of these changes have involved the adoption of official dual names in both Māori and English. For example, Mount Cook is now listed as Aoraki/Mount Cook. Many names, including those changed by the Ngāi Tahu settlement, now appear on New Zealand maps in this sort of dual format (McKinnon, 2013).

There has been a reaction against the imposition of colonial terminology at a more personal level, too. For instance, as a corrective to Christian baptism practices that encouraged the adoption of English Christian names and family names, there has been a renaissance in Māori naming practices (Smith, 1999). As Smith notes, 'Indigenous names carried histories of people, places and events' (1999, p. 157), and the practice of naming children with long ancestral names, in addition to taking on new names through life, has been reasserted by many Māori families.

Finally, there have been intensive struggles over how te reo Māori (the Māori language) and Māori language concepts have been applied in English language contexts (Te
Taura Whiri i te Reo Māori/Māori Language Commission, 2012). In addition to demands for the correct pronunciation of Māori words and place names and the adoption of certain conventions to indicate vowel length, there has been a focus on the best practices for spelling and writing in Māori. Some New Zealand newspaper editors and publishing houses, for instance, have insisted on pluralising Māori words by attaching an 's' to Māori language terms in English language publications. In Māori, however, tense and plurality are indicated by separate words. Because of this, many of those involved in language revitalisation programs insist that Māori words used in written English contexts be subject to the grammatical rules of the Māori language, which do not make use of the plural suffix 's'.

There have also been controversial debates over the use of, and capitalisation of, the word 'Pākehā'. 'Pākehā' is a Māori language term applied to the descendants of British settlers whose cultural values and behaviour have been primarily formed from the experiences of being in New Zealand. This term is rejected, often strongly, by those either uncomfortable with the Indigenous cultural renaissance that has taken place in New Zealand since the late 1960s and early 1970s, and/or threatened by the political demands of Māori for self-determination (Fleras \& Spoonley, 1999). Some commentators have even maintained (erroneously) that the word 'Pākehā' should be rejected because it implies something derogatory (Pearson \& Sissons, 1997). There has also been a significant reaction against those who profess to being Pākehā and the cultural politics of the 1980s that encouraged such selfidentification (e.g., Bedggood, 1997; Fleras \& Spoonley, 1999; Pearson \& Sissons, 1997). Callister (2004) notes, for instance, that one of the most common complaints to New Zealand's former Race Relations Office was from people objecting to being labelled 'Pakeha'.

The examples that I have highlighted above reflect the naming protocols and conventions that have evolved in a context in which there are established (albeit contested) systems of meaning. This creates an interesting challenge for those of us working in global Indigenous contexts where different sets of conventions apply. This highlights the importance of recognising that the connections between language, power and resistance occur in specific historical and societal contexts.

This, of course, points to the importance of understanding New Zealand's specific historical context. The use of the noun 'Māori' as a self-referential term and as a means to categorise and describe the Indigenous inhabitants of New Zealand is relatively recent in origin. As an adjective, the word 'Māori' means 'normal', 'usual', or 'ordinary' and was used historically to describe anything in its natural state. As an adverb, the word 'Māori' means 'freely', 'without restraint', and 'without ceremony' (William, 1992, p. 179).

Although there is some evidence that the term 'Māori' was in use prior to 1815 to describe the quality of being 
'native' or belonging to New Zealand, early European settlers, traders, and explorers invariably spoke of 'Natives', 'Aboriginals', or 'Indians'. These were, of course, wellrehearsed categories that had emerged as the lingua franca of European colonial encounters with Indigenous peoples globally.

With the legal and statutory recognition of New Zealand as an independent sovereign territory outside British dominion in 1817, many colonial administrators, missionaries and settlers simply referred to the local inhabitants by the more generic label 'New Zealanders' (McLintock, 1966). This became more problematic with the annexation of New Zealand as a formal British settler colony in 1840 and the subsequent rapid influx of predominantly British settlers. The term 'New Zealander' would no longer remain the preserve of Indigenous communities.

From the mid-19th century, the word 'Māori' was increasingly used as a noun to differentiate the Indigenous inhabitants of Aotearoa/New Zealand from the new European arrivals (Williams, 1971, p. 179). One of the earliest documented examples of the use of the word 'Māori' in this way in written English dates from the 1850s (Cooper, 1851, p. 204). In this sense, the notion of a 'Māori race' or people co-existed with, and eventually superseded, other official British Colonial Office descriptors employed in the New Zealand context (although the more pejorative and widely used 'Native' continued to be employed in official State business). In fact, it was not until 1947 with the introduction of the Mãori Purposes Act that the Department responsible for the administration of Indigenous affairs in New Zealand changed its nomenclature from the Department of Native Affairs to the Department of Māori Affairs.

Some have responded to the evolution of a sense of Māori ethnicity by claiming that it represents an invention of tradition' that is not a natural product of an essentially tribal people. The idea that authentic Māori identities are essentially iwi-based identities has been articulated by a number of prominent Māori leaders. Sometimes such an argument involves a suspicion about the state's historical encouragement of pan-tribalism and the cultural homogeneity that is implicit in the concept of 'Māori ethnicity' (e.g., Rangihau, 1992; O'Regan, as cited in Melbourne, 1995).

The significant upsurge in Māori protest and resistance from the late 1960s onwards has seen a greater focus on challenging the legacies of colonial categories. This has involved reclaiming the power to define who Māori are by emphasising the significance of 'whakapapa' (the genealogical connections of individuals and groups to particular ancestors) rather than the imposition of racial categories based on phenotypical characteristics (usually skin colour) or blood quantum. Although assumptions about the physical characteristics and traits associated with being Māori continue to shape social interactions in wider
New Zealand society, the political context is obviously different for Indigenous communities internationally where categories based on blood quantum still exert a profound influence on governance arrangements (Sissons, 2005, p. 43).

\section{Native American Jeff Berglund}

I teach Indigenous literature and film in the southwestern United States at Northern Arizona University, which is nearby the most populous Indian reservation, the Navajo Nation. The state of Arizona is home to 22 federally recognised sovereign Indian nations. Despite the proximity to these Indigenous cultures and communities, the majority of my students have never had open discussions about nomenclature and the history of different naming practices. During a discussion of terminology in a past subject, one of my students noted:

I have always tried to be careful with racial and ethnic labels as it is a sensitive issue for many people. However, I have always been unsure about correct terminology when it comes to Native American cultures. A good friend of mine is Navajo and says that his tribe refers to themselves as 'First Peoples' and prefer this term over 'American Indian' or 'Native American'. 'First Peoples' just doesn't seem like an appropriate term to use in an academic setting; should I stick to more general terms like 'Native American' or 'American Indian'?

This student's questions are the rule rather than the exception, and year after year I contend with similar sorts of volleys regarding appropriate nomenclature. Despite my students' concern about the term 'First Peoples', it is not inappropriate, and is, in fact, a term that is used with increasing frequency, especially among historians and within museum studies. My sense is that the term is kin to 'First Australians' and, in Canada, to 'First Nations'. Of these terms, 'First Nations' is used regularly as a modifier to define the work of Indigenous people from Canada. For example, 'First Nations literature', 'First Nations filmmaker', or 'First Nations Studies', and so forth (htpp://indigenousfoundations.arts.ubc.ca).

The questions about terminology are even more complex when I move into a comparative situation in my subject on trans-global Indigenous cinema that looks at films in Australia, New Zealand and the United States. The term 'Blackfella', as my co-author, Harris, notes, is particularly confusing for U.S.-based students. For example, in teaching a film such as Wayne Blair's The Sapphires (2012), understanding the Australian context is crucial in parsing the relevance of particular terms. Indigenous Australian characters are referred to as 'Blackfellas' or 'Blacks'; but, when Indigenous Australian characters travel outside of Australia to entertain troops during the Vietnam War, they meet U.S.-enlisted African American men who refer to themselves as 'Black'. Similar distinctions are vital when discussing Rachel Perkin's Freedom Ride (1993) with its 
contextualising parallels with the U.S. Civil Rights Movement. While I discuss nomenclature in all of my American Indian-focused subjects, the complexity of navigating terminology increases in manifold ways in subjects on global Indigeneities.

In the context of the United States, 'American Indian' and 'Native American' are the most commonly used terms to refer to Indigenous peoples living in the boundaries of the continental United States. In these 48 states, there exist over 566 federally recognised tribes. While the federal government determines official recognition of tribes, it remands control of tribal enrolment and membership to the tribal nation itself. In many cases, though, dominant national notions of 'race' and 'blood quantum' determine enrolment policies, thus indirectly controlling how tribal nations determine membership. Members of these tribal sovereign nations are recognised for census purposes as 'American Indian', the term used by the U.S. federal government. Since 1924's Indian Citizenship Act, American Indian people are United States citizens. 'American Indian' is the term used by the United States federal government and major academic organisations and their affiliated journals, giving credence to its use in academic situations. A few examples illustrate this trend: key journals consist of American Indian Quarterly, American Indian Culture \& Research Journal and Studies in American Indian Literature. In the state of Arizona, Arizona State University, one of the largest universities in the United States, houses the American Indian Studies Department, as does the University of Arizona. AISA, the American Indian Studies Association, is also a key organisation linking academic units across many institutions.

Clearly, there's no fixed consensus on appropriate terminology, as a frequent alternative to 'American Indian' is 'Native American', a term that came into usage in the 1960s and 1970s, signalling an evolution away from the term 'Indian'. In contrast to the naming practices in institutions and organisations listed above, Northern Arizona University houses the Department of Applied Indigenous Studies, and under non-academic arenas features the Native American Cultural Center, Native American Student Services and the Commission for Native Americans. A major international organisation known by the acronym NAISA struggled with the challenges of nomenclature and finally approved its name, Native American and Indigenous Studies Association. The Native American Literature Symposium (NALS) has employed this term for well over a decade, as well. Thus, the modifier 'Native', always capitalised, is an acceptable usage in the United States, and it is common to hear academics speaking of Native history, Native literature, and Native culture. By contrast, the word 'Native' in an Australian or New Zealand contexts has negative implications and generally should not be substituted in the place of 'Indigenous', despite its status as a synonym in North American. In Australia and New Zealand, the word 'Native' or 'native' connotes something closer to 'savage' or 'heathen', as it is intimately connected to the colonialist clichés 'the natives are restless' or 'going native'.

Indigenous peoples living on the land and waters of the state of Alaska are recognised by the United States government as 'Alaskan Natives'. This term is distinct for this geographic region and recognises particular cultural, political, and legal histories. The term 'Alaskan Native' was codified by the Alaska Native Claims Settlement Act (ANCSA) in 1971 which established 'thirteen regional and over 200 village corporations' as a means of asserting Indigenous rights over lands seized by first Russia and then the United States in its purchase of territories from Russia. Distinct tribal groups exist in Alaska, but besides referring to members of these 229 tribes or villages by their specific names (e.g., Aleut, Haida, Inupiaq, Athabascan, Tlingit, Yu'pik, and so on), the all-encompassing 'Alaskan Native' is the most accurate, not to be confused with 'native Alaskan', referring to non-Indigenous peoples whose histories in this state are limited. The term 'Eskimo' is an outdated term and has no practical use in discussions of contemporary Alaska Natives (Roderick, 2008).

'Native Hawaiian' is a term reserved for Indigenous people of the Hawaiian Islands who are not recognised as 'American Indians' or as having the rights of other sovereign tribal nations. Since annexation in 1898, Native Hawaiians have been U.S. citizens. 'Kanaka Maoli' is how many Native Hawaiians refer to themselves (Kelea Kelly, 2009). Currently, the Bureau of Indian Affairs (BIA), a division of the United States Department of the Interior, does not oversee the affairs of Native Hawaiians. While legislation (The Native Hawaiian Government Reorganization Act) was first introduced in 2007 in a bill before the House and Senate, and again in 2010 and 2011, it was never passed. Senator Akaka of Hawaii introduced the legislation to establish a procedure for Native Hawaiians to seek federal recognition from the BIA or the U.S. government and to establish within the state of Hawaii a sovereign nation-to-nation state of Native Hawaiians (Loomis, 2009).

'Indian' is a term used within Native communities (almost as a reclaimed name), though it is not as commonly used by non-Natives. Authors and filmmakers will use this term, so it will likely be encountered, but I recommend that outsiders to Indigenous communities only use this term if authors or artists employ the term. No matter one's take on the term 'Indian', it's worth noting how the word came into common usage. There are several accounts about its origin in the colonial encounter in the Amerícas. One theory links the term with Columbus' mistaken assumption that he had reached India, his original destination. If this is the word's origin, no matter Columbus' later recognition of his error, the word was born of inaccuracy. Others have suggested that the term 'Indian' originated in a Spanish phrase that means the people of God, men created in the image of God: en díos, or indios, of which the latter translates from Spanish into English as 
'Indian'. This positive rendering is also suspect for several reasons, the primary being what Columbus and others did to the Indigenous inhabitants of the new world. The vocabulary coming of out of this 'encounter' is manifold. The term 'Caribe', a name referring to the indigenous people of the island of Hispaniola, which came into the Spanish lexicon as 'canibale', soon became a synonym for 'anthropophagite' - what is commonly referred to as 'cannibal' today - yet another reason why it's hard to see 'indios' as having a positive connotation (Berglund, 2006).

Historically, 'Indian' was used with great frequency and acquired over time a great deal of negative connotations, even spawning the racial epithet, 'Injun'. 'Indian' can also introduce confusion. In the U.S. context, if the word is used, it often begs the question about whether someone is Indigenous or whether someone is from heritage connected to India or its diaspora. Today, there is disagreement about the value of the term 'Indian'. Writer and theorist Gerald Vizenor (Anishinabe) contends that 'Indian' is a 'simulation', a substitution that now dominates and erases/eliminates the complexities and realities of Indigenous peoples (Vizenor, 1999, pp. 5-6). According to Vizenor, the term 'Indian' flattens out the rich and vibrant realities of incredibly diverse Indigenous peoples. An additional way that 'Indian' is misleading and inaccurate is its levelling of the complexities of many cultures and language groups. To group peoples with highly advanced and differentiable languages, spiritual worldviews, cosmologies, political and economic systems, specific relationships with the land and geography, and social structures related to gender and age - to refer to people from such disparate backgrounds by the same name is grossly inaccurate. Labels and terms condense meanings and complicated histories and thus reveal or thwart the confirmation of particular assumptions about identity. Stereotypes about 'Indians' are circulated widely in mass media; movies, in particular, have perpetuated limited understandings of Native peoples and this, coupled with an absence of academic attention to Native peoples' histories, has led to widespread ignorance of American Indians, even the burden of expectation foisted on emerging artists and filmmakers (Berglund, 2013). Furthermore, American sports mascots - the Washington Redskins professional football team, the Cleveland Indians professional baseball team, the Atlanta Braves professional baseball team, the University of Florida Seminoles, the University of Illinois Fighting Illini, the University of North Dakota Fighting Sioux - all further circulate an extensive range of stereotypes and create situations for many non-Native fans to perform 'red face,' to adopt stereotypical renderings of 'Indians'.

In contrast to misgivings about inaccuracies associated with the term 'Indian', there are a number of Indigenous people who accept, if not prefer, the use of this term. Again, context is everything. In an interesting qualitative survey of Indigenous academics, Michael Yellow Bird (1999) discovered that almost half of the respondents feel the term 'American Indian' or 'Indian' is more acceptable than 'Native American' to the general population of Indigenous Peoples. The most often cited reason for the acceptance of the label is that it has been used for a long time and it is familiar to most, especially elderly, First Nations Peoples. All said 'Indian' is the label they hear most often in their social interactions with other Indigenous Peoples, so they have become comfortable with the term (Yellow Bird, 1999, p. 3). Further support for this viewpoint can be found in the words of prominent Spokane \& Couer d'Alene writer, Sherman Alexie. He shares this anecdote in his essay, 'The Unauthorized Autobiography of Me':

Thesis: I have never met a Native American. Thesis reiterated: I have met thousands of Indians... The word belongs to us now. We are Indians. That has nothing to do with Indians from India. We are not American Indians. We are Indians, pronounced Indin. It belongs to us. We own it and we're not going to give it back.

So much has been taken from us that we hold on to the smallest things with all the strength we have left. (Alexie, 2000, p. 4)

Sherman Alexie's usage represents a reclamation, a refusal of its negative connotations. Moreover, his rejection of 'Native American' seems rooted in disdain for political correctness and calculated efforts to avoid terms fraught with colonial and racist histories (Berglund, 2010).

To fully recognise the specificity and complexity of Indigenous peoples in the United States, and to avoid some of the shortcomings outlined above, I recommend that my students rely, if possible, on tribally specific names for individuals who are enrolled in particular tribal sovereign nations, though generic terms might be necessary when referring to general experiences or to groupings of individuals from more than tribe. If a Native person is from the Navajo Nation, for example, appropriate terms are 'Navajo' or 'Diné' (which is a pre-colonial name meaning 'The People'). Today, American Indian nations are also engaged in language revitalising efforts and are striving to reclaim original names, throwing off imposed terms: Ojibwe or Anishinabe people, for example, used to be called Chippewa; Lakota people used to be called Sioux; Tohono o'odham people used to be called Papago; and so forth. People from mixed tribal background will either identify their multiple lines of descent or will choose to identify with the tribal nation with whom they are enrolled.

While not preferred in many international contexts today, the term 'tribe' is used in the U.S. context. In its place, 'nation' is sometimes used. Official websites and promotional materials from various tribal nations signal preferred terms. For example, there is 'The Spokane Tribe', 'The Cherokee Nation', 'The Hopi Tribe', and 'The Lakota Nation'. Anton Treuer, in Everything You Wanted to Know about Indians but Were Afraid to Ask, suggests that the term 
'tribe' came into existence when European colonial powers began to 'simplify the politics so they could get at Indian land faster. That process started with the construction of new labels for native communities that in turn helped the evolution of new Indian political structures' (Treuer, 2012, p. 11). For all practical purposes today, the term 'tribe' is both used, according to Treuer, 'as a label for all people of the same shared cultural group (as for the Ojibwe in their two hundred distinct communities) and also as a label for each reservation's government' (Treuer, 2012, p. 12).

For most federally recognised tribes, 'reservations' are now sovereign landbases, political entities (with distinctive governance structures) called 'nations', that emerged out of treaty negotiations or other government actions. Today in the United States reservations occupy only $2.3 \%$ of the entire nation's landbase. Reservations first came into existence in the late 19th century. According to the Bureau of Indian Affairs, 'a federal Indian reservation' is an area of land reserved for a tribe or tribes under treaty or other agreement with the United States, executive order, or federal statute or administrative action as permanent tribal homelands, and where the federal government holds title to the land in trust on behalf of the tribe' (Bureau of Indian Affairs, n.d.). The nickname 'rez' is often used within specific geographic or cultural contexts. Similarly, the terms 'homeland' or 'sacred homeland' are used to signify culturally significant landbases that may or may not be recognised by current geopolitical boundaries, something perhaps akin to the use of 'country' in the Indigenous Australian context.

\section{Blacks}

\section{Michelle Harris}

On my first trip to Australia well over a decade ago, I was intrigued to meet Indigenous Australians who referenced themselves as 'Blackfellas'. Many, in my opinion, had no visible racial markers of being 'black' in the skin-tone or phenotypical sense of Blackness that those of us from the Americas come to know. As a person who identifies as racially Black, I wondered why someone who didn't wear visible markers of this racial designation would choose to identify in this way. On the heels of that thought came another: here was one of those alternate conceptions of 'race' (both in a literal and political sense) that I taught my students about; I was about to move from the realm of intellectual knowledge to the lived experience.

I hasten to say that, like most social scientists, I accept that race-as-biology is a myth and believe that while race is a social construct, its implications for one's life, and the consequences of a belief in the immutable differences between people of different races are real and significant in the everyday lived experiences - especially for people of colour. I therefore use the term 'Black' to refer to groups of people who, in the U.S. context, are considered to have African ancestry.
American students who enter societies like Australia or Brazil, where different conceptions of race are understood, and nomenclature attached to non-white members of the society differ from that which is used in the United States, often experience moments of disconnect, confusion, or questioning. Americans, of course, come from a society where the need to be current, non-insulting and politically correct in our racial labelling is very important. When students are Black Americans/African American/Afro Americans/African/Afro-Caribbean, the practice and politics of naming can be even more fraught than it may be for White students. The anxiety, I contend is, in part, wrapped up in Blacks' struggle with collective self-identity, which is by no means uniform.

In the United States, Blacks called themselves Africans until the early 1800s. Several name changes ensued from that time to the present - 'Afro-Americans', 'tan', 'coloured, 'negro', 'Negro', 'Black', and 'African American'. Most of these evolutions in nomenclature occurred alongside vigorous political debates about the meanings and political implications of said name. Little uniformity of opinion was ever present among Blacks at these junctures of change. They have never constituted an ethnic monolith in America or the diaspora in terms of heritage, ideology, or experience. Even within the contemporary United States, Blacks as descendants of enslaved Africans claim different histories as a function of ancestral ties to the north (where many Blacks lived as freed men long before slavery was abolished) or to the south.

Afro Caribbean immigrants and their offspring also do not represent a unified group: they divide themselves along lines of mother tongue - English-speaking, Spanish-speaking, and Francophone. Additionally, while many American-born descendants of immigrants from the West Indies are comfortable with being called either African American or Black, people of their parents' or grandparents' generation may object to being called either of those names; 'African American' obscures their cultural heritage, and 'Black' seems starkly confrontational or reeks of undesirable racial qualities.

More recent immigrants from Africa (and their descendants), too, consider themselves (and are often considered) ethnically, if not 'racially', distinct from other Blacks in America. Though the term 'African American' may seem to best fit their situation, it is certainly a term that means something that is not reflective of their particular situation. Moreover, some people from the African continent resent the monolithic 'African' as it obscures some other designations that they feel better describes them; these may include nationality (e.g., Tanzanian) or tribal affiliation (Maasai). This illuminates an important point, which is that Blacks' choice of preferred nomenclature is often likely to reflect a real or constructed ethnicity (e.g., African or Caribbean) - a necessary ingredient if one is to build community and foster feelings of loyalty and belonging among group members (di Leonardo, 1984). 
Of course, this begs the thorny questions about community - how can we tell the community to which a person may feel attached, and once we know that, what is the proper way to make reference to it? Am I safe in calling all 'racially' black people, 'Black', and hope that they will see that my goal is to be well meaning and inoffensive? Since Indigenous Australians (who refer to themselves as Blackfellas) sometimes talk about their collective as a 'mob', or 'my people', may I use similar terms when talking about Blacks from the Americas or from Africa?

Here are the answers to these questions. Communities, especially those built along seemingly racial lines, can be fluid and fragile. One major reason for this is because a name like 'African American' probably obscures as much as it illuminates. Other than identifying a visible 'racial' category, we are really left in the dark about how a particular individual may see herself in relation to those around her, and to remove us from the social (from those around us) is to create an artificial reality. Racial and/or ethnic nomenclature does not always give us information about the people with whom one may most closely identify. The best way to know that is to ask. Asking is also a good way to ascertain information about how people would like you to reference them and their group. While neither 'mob' nor 'tribe' are terms African Americans and Caribbean American use to talk about others in their ethnic group, Blacks who are more recently from an African nation may use the designation of tribe. With so much variation among a group that shares the same 'race', the best way to cause no offence (and to distinguish oneself as caring enough to get it right) is to ask. Relying on visible cues to guide us in our assumptions about a person's racial/ethnic identity is also not reliable. While there is sometimes a relationship between how a person looks and how they might identify themselves, sometimes there is not.

\section{Aboriginal and Torres Strait Islander Australia Bronwyn Carlson}

In Australia there are two distinct Indigenous groups: Aboriginal peoples and Torres Strait Islander peoples. However, these terms are relatively impoverished, as they do not adequately describe the existence of hundreds of selfidentifying and named autonomous groups across the continent and surrounding islands. Since colonisation, Indigenous Australians have been understood and named by Europeans in ways that have no foundations within any of the many languages of Aboriginal peoples and Torres Strait Islander peoples; generally named as a collective, with the assumption that regardless of geographical location, histories and experiences, or the way we know and describe ourselves, we are all the same.

Beginning with the term 'aborigine', Indigenous Australians were constructed as primitive natives and understood in terms of their distance from 'civilised'
Europeans. Considered 'archaic survivors from the dawn of man's existence' (Attwood \& Markus, 1997, p. 1), 'full blood' Indigenous Australians were assumed to be a 'dying race' - 'the wandering savage ... doomed to extinction by the progress of that type of humanity with which it was impossible to assimilate him' (Turner 1904, as cited in Attwood \& Markus, 1997, p. 1). In keeping with the 'dying race' narrative, various 'protection' policies began to be developed from the mid-1800s. Under this regime, reserves and missions were established as a way of managing the so-called 'remnant' Indigenous populations. The strategy was twofold: 'protection' and segregation. Indigenous populations fell into either category depending upon their supposed quantum of Aboriginal and/or European blood. Those considered to be 'full blood' were to be 'protected' and sent to reserves as part of a 'dying race' and those considered to be 'part Aboriginal' (commonly used terms at the time include 'half caste', 'quadroon' or 'octoroon') were to be segregated and sent to missions. This began the insidious practice of forced removal of Aboriginal children from their families - those who were forcibly removed are now known as members of the Stolen Generations (http://www.humanrights.gov.au/publications/bringingthem-home-stolen-children-report-1997). The explicit target of such policies and practices were those considered to be 'part Aboriginal'. Forcibly removing Aboriginal children from their families continued in Australia well into the 1970s. Much of this policy era was driven by a eugenics agenda based on the perceived possibility of 'breeding out' the remainder of the Indigenous populations that had not 'dyed out' on reserves. There was, and arguably is, the opinion that if one does not 'look' Aboriginal one would choose not to 'be' Aboriginal. This thinking was highlighted in the 2002 Australian film Rabbit Proof Fence where the character A.O. Neville, 'Chief Protector of Aborigines' in Western Australia (from 1915 to 1936), is depicted as describing his success in 'breeding out' Aboriginality over three generations. Neville went on to publish his ideas for the biological absorption of Aboriginal people into the white population in his text Australia's Coloured Minority (Neville, 1947). In the development of policies and legislation in regard to the Indigenous populations, terms such as 'full blood' and 'half caste' were introduced into the Australian vernacular, embedding explicatory understandings of who such terms are describing.

The categorisation of Indigenous Australians based on blood quantum during this era has had lasting affects and arguably still informs the general population about who can count as Indigenous in Australia (Carlson, 2011). It is not uncommon, across all levels of society, to see debates about who or what counts as Aboriginal. In fact, at times, it can appear to be a constant concern of the public and can incite a frenzy of commentary about 'who' is Aboriginal and 'what' are the characteristics that 
evidence and confirm any legitimate claim to 'be' an Aboriginal person. Many of the historical terms and categories based on blood quantum, while they should be considered derogatory and offensive, continue to appear in both academic and public discourse; for example, the recent Andrew Bolt saga. In 2009, nine prominent 'fair-skinned' Indigenous people brought a Racial Discrimination case against the journalist Andrew Bolt for comments in four of his columns, including one article entitled 'White is the New Black' (Bolt, 2009). Bolt was objecting to successful 'light-skinned' Aboriginal people 'choosing' to be Aboriginal when they, according to Bolt, could have chosen any one of a number of non-Aboriginal heritages (for a discussion of the Andrew Bolt saga, see, e.g., Bodkin-Andrews \& Carlson, 2013, pp. 46-48; Kearney, 2013, p. 245).

Terminology, particularly as it relates to Indigenous populations can be complicated to navigate and some may consider terms accepted by others offensive or unacceptable. Aboriginal and Torres Strait Islander people do not unanimously agree on which terminology is acceptable and why would we? There is great diversity among Aboriginal and Torres Strait Islander people and cultures. Moreover, there is also a diverse range of experiences in relation to colonisation, which also impacts the way in which particular groups are defined or indeed define themselves (e.g., Bodkin-Andrews \& Carlson, 2013). My doctoral thesis provides a detailed study of the politics of who counts as Aboriginal in contemporary Australia. As part of the research process, I realised that by tracing the production, via a gargantuan pile of material, of 'who and what Aboriginal people are' over time, I was able to reveal that our own possibilities for remaining and 'being' ourselves have been tightly circumscribed by 'other' discourses about us (Carlson, 2011).

To exemplify, in a recent television show on the Australian SBS network, Insight, the politics of Aboriginal identity was fiercely debated (Nakata, 2013a). During the discussion a member of the audience stated that she did not want to be referred to as 'Indigenous' as she considered herself Aboriginal. In response, another member stated, 'I am not Aboriginal, I am Warlpiri'. Nomenclature in regard to Indigenous Australians is vexed and cannot overlook the historical context from which it has emerged. The members of the audience on this television program came from different and varied cultures and experiences: one identified as being a member of the Stolen Generations; one indicated that she lived in an urban setting; and another, a more remote location on Aboriginal lands. In another example, an Aboriginal academic publically announced that he is 'part-Aboriginal', a term that has significant historical meaning to some, especially, but not exclusively, members of the Stolen Generations. In an article discussing his views, he stated that he identifies as:

... a part-Aboriginal person. I have been told that use of the term 'part-Aboriginal' is offensive and that I should not use it.
Nonsense. I can describe myself in any way I wish. People, in their concern/criticism, sometimes say, 'Well which part of you is Aboriginal?' Or some Aboriginal-identifying people may say, 'Well I am a whole person, I am not 'part anything.' (Dillon, 2012)

Dillon argues that he is a 'whole person' and in his explanation suggests that 'part' of the whole is Aboriginal, therefore he recognises himself as 'part Aboriginal'. Many other Indigenous Australians, however, reject terms that have emerged as part of the colonial practices of determining Aboriginal identity based on blood quantum and, as noted, those who suffered under policies directed at people labelled as 'part-Aboriginal' find such terms difficult to accept. Many prefer to acknowledge their non-Indigenous heritage by saying they are Aboriginal and (whatever their other heritage may be). The complex and at times contentious nature of nomenclature in regard to Indigenous peoples in Australia is evident in these examples. They are also a reminder that the tensions in regard to naming and being named are historically embedded and that 'the threads of older discourses persist into the present' (Carlson, 2011, p. 386).

Despite the contestation and involvedness of terminology, many Indigenous Australians accept the terms 'Aboriginal people' and 'Torres Strait Islander people' as an overall descriptor. However, as noted above, the term 'Indigenous' can also be highly contentious. While many accept 'Aboriginal', there continues to be a lot of debate over the term 'Indigenous'. Several Aboriginal people have told me that they dislike the term 'Indigenous' because they consider it a government-imposed term popular with bureaucrats, because repeatedly writing Aboriginal and Torres Strait Islander is viewed as cumbersome. There is also a view that the term 'Indigenous', while meaning to include both Aboriginal and Torres Strait Islander peoples, further homogenises the two groups. As Arrernte woman Celeste Liddle (2014) notes, 'a lot of our community organisations are currently dropping the term "Indigenous" (which came into popular usage when Amanda Vanstone was the Minister for Indigenous Affairs)'. Liddle goes on to state that, 'there's also the fact that it only means "native to the land" when the alternative, "Aborigine" means "an original inhabitant of a country or region who has been there from the earliest known times"' (2014). Non-Aboriginal people who claim to be an 'indigenous Australian' is also becoming an everyday occurrence. A recent example is columnist Andrew Bolt, who claims that he is '.. an indigenous Australian ... I was born here, I live here and I call no other country home. I am therefore indigenous to this land and have as much right as anyone to it' (Bolt, 2014). This type of grandstanding, as Liddle (2014) articulates, is generally about discrediting 'the unique status that Aboriginal and Torres Strait Islander people hold as "first peoples" of this country'. In the global context, however, there is more 
acceptance for the use of the term 'Indigenous'. Aboriginal and Torres Strait Islander peoples generally accept an international identity as an Indigenous group. We are Aboriginal and Torres Strait Islander peoples and we are part of the world's Indigenous population.

As an Indigenous Studies practitioner I have found that ensuring students understand and acknowledge the diversity of Aboriginal and Torres Strait Islander peoples, communities and cultures is crucial. Students often struggle with the idea that Aboriginal and Torres Strait Islander people are not a homogenous group and are surprised to learn that the majority of Indigenous Australians live in urban locations, particularly western Sydney in New South Wales and Brisbane in Queensland. Likewise, students are often 'befuddled by terminology' (McGloin \& Carlson, 2013, p. 2), at times keen to 'get it right', but at other times annoyed and frustrated that consideration should be given to appropriate nomenclature, and become upset when marks are deducted if they are not attentive to appropriate terminology. Many students do not consider the historical significance of colonial labels or that such names can have real effects for Aboriginal and Torres Strait Islander people, as highlighted here by McGloin and Carlson:

Aboriginal and Torres Strait Islander peoples have been historically constructed according to a vast array of linguistic representations that posit the opposition of these cultures to white, western cultures. Colonial representations of 'others' are not merely harmful in terms of language; the construction of otherness through language continues to have devastating effects through policies that regulate and dictate the daily lives of many Aboriginal and Torres Strait Islander people. Language, then, is political: it has real effects. $(2013$, p. 2)

The use of the term 'Aborigine' is not generally favoured, and either with a capital 'A' or lower case 'a' it is considered an anachronism. Being referred to as an 'Aborigine' reminds many of a time when Aboriginal people were classified as non-human and were counted under the Flora and Fauna Act (Cth). This is not ancient history: being counted as flora and fauna is very real for many older Aboriginal people. For many, being counted as human came only after the 1967 referendum and the subsequent 1971 census. The 'real effects' of labels can also be generational and may have different meanings for different people depending on their age group and experiences. Nakata (2013b) shared a story of a person advocating for the rejection of the term 'Indigenous'. As the person spoke, Nakata noticed that he continually used the term 'mob' to refer to Aboriginal people as a collective. 'Mob' is an everyday term used by Aboriginal people, as opposed to terms like 'tribe':

What struck me most though was that throughout his speech he constantly referred to us as 'mob'. I'm old enough to know that this was the term used commonly by farmers in Australia for cattle. (Nakata, 2013b, p. 294)
Similar to Nakata's account, in a recent Facebook conversation about Aboriginal unity, an older Aboriginal man posted his disputation about the use of the term 'mob'. He was challenging younger Aboriginal people's usage of the term 'mob' to refer to family groups, community groups or as a collective descriptor for all Aboriginal people 'us mob'. He posted that this term originated from the time when Aboriginal people were counted as a mob of cattle.

Language, however, can be reappropriated, and some Indigenous Australians have taken possession of various derogatory labels and have renegotiated the meaning of the words and through reappropriation imbued the terms with positive connotations. For example, some Aboriginal people have reappropriated the meaning of terms like 'Aborigine' or 'mob' - notably in the lyrics to the catchy song, Proud to be Aborigine by Tjapukai singers; and Us $M o b$ is the name of a 1970s Aboriginal rock band from South Australia. Liddle (2014) is an advocate of reclaiming terms and suggests that she likes 'reclaimed terms ... such as "mob" (our people). That term was used pejoratively when we were considered no more than animals, but we've since adopted it and it's now a commonly used colloquial term in the community is something I enjoy'.

However, the key to reappropriation is consensus from the group that the uses of such terms are accepted as reclaimed and refined. This is not always the case. In a poignant example, the female band Stiff Gins caused some controversy with their use of the term 'gin'. Demonstrating the insidious history of the term 'gin', in a newspaper article in 1984, 83-year-old Western Australian man, Xavier Herbert was quoted boasting that he was 'the biggest gin rooter around' and stated that, 'We used to go up to Broome for our holidays and I knew, all through Western Australia, black velvet was the thing. It's changed a lot in recent years but the perfect mate for the bushman was the black girl.... The pearling industry was established in Broome and the pearlers used to go up into the Kimberley country and steal the young [Aboriginal] gins to work as pearl divers. Of course, they used to rape them, too, and when they got too pregnant they'd chuck them overboard' (Ramsey, 2008). The singers, however, stated they had taken the term which has been long used to denigrate Aboriginal women and reclaimed it for themselves, declaring its meaning as 'talented, proud and passionate' (http://www.last.fm/music/Stiff+Gins). The Aboriginal musicians suggested that they have taken the derogatory term and confronted its meaning, and in doing so have defused its impact and stigma. Some older Aboriginal women were not so convinced. As with the term 'mob', responses from Indigenous Australians can vary depending a variety of factors, including gender and age. For some, derogatory terms are not so far in the distant past that they are no longer affected by them. It is advisable to give a great deal of consideration and caution when using terms that have been imposed on particular groups. 
As demonstrated by the conversation on the SBS program, Aboriginal people may prefer to be called by the language/cultural/skin/clan groups or communities to which they belong. That is, their own names rather than terms such as 'Aborigines' or the 'Aboriginals'. In the Illawarra region, where UOW is situated, Aboriginal people may refer to themselves as Wodi Wodi or Dharawal. It is common to hear of particular Aboriginal peoples being referred to by other names that are connected to the particular region a person may be from; for example, Koori - New South Wales and Victoria; Murri - Queensland; Nunga — South Australia; Noongar — South West and North Western Australia; Yolngu — Northern Territory top end; Anangu — Northern Territory central; and Palawa - Tasmania; and so forth. Aboriginal people often use these terms to refer to each other, but some caution should be taken in using such names to ensure that the individuals being referred to are in fact from those regions and are willing to be identified in that way. Just as if you were visiting any new place, the best advice is to check the correct name or terms to use for people in the area/region.

The terms 'Blackfella' and 'Whitefella' (at times spelt Blackfulla) are colloquial terms used by Aboriginal people. These terms do not necessarily refer to skin colour but denote one's Aboriginal identity (Blackfella) and identifies one as non-Aboriginal (Whitefella). The term 'Blackfella' or 'Black' as Liddle (2014) notes, 'is a word that has power' and is a term that Aboriginal people have reclaimed:

After years of removal policies and stolen generations based on the tone of one's skin and their alleged blood quanta, to state that you are 'Black' regardless is defiant. It proclaims resilience in the face of harsh assimilation policies proudly. People sometimes fear that otherness, when what they should do is embrace it and recognise that it is important and something to celebrate. (Liddle, 2014)

Contrary to the views of some commentators, skin colour ('being Black') or specific phenotypical traits do not necessarily signify that a person is Aboriginal and/or Torres Strait Islander. Students have on many occasions asked me about Aboriginality and inquired as to where a line should be drawn that indicates a point when a person is no longer Aboriginal - by this they are generally referring to skin colour and they struggle to comprehend that Aboriginality is not necessarily visible in the way they may assume it should be. Their thinking is that Aboriginal identity begins with someone 'full blood' and as one's heritage includes non-Aboriginal people, there should be some sort of cutoff point (the assumption being that Aboriginality can be diluted - an idea held by A.O. Neville). I ask them to consider their own family and question them about when they would apply the cut-off point. Our family members do not stop being our family because one is fairer or darker or has different coloured eyes or hair and so forth.

It is useful to remember that 'Aboriginal', 'Torres Strait Islander,' 'Indigenous' and so forth are all names that have been imposed on us as diverse groups of people at various points in history. As Nakata reminds us, both 'Aboriginal' and 'Indigenous' are 'Whitefella words' (2013b, p. 294). For students studying in Indigenous Studies programs, it is important to bear in mind that language is political and the construction of otherness through language can be harmful and offensive and can have devastating effects on particular groups (McGloin \& Carlson, 2013, p. 2).

\section{Concluding Remarks}

In our view, accurate terminology and names are important for a variety of reasons. First and foremost in an academic setting is accuracy. Within university settings and academia, broadly speaking, using accurate and agreedupon vocabulary is crucial. Learning new concepts, new vocabularies and definitions alongside their historical developments is part and parcel of the experience of study and of mastery. Thus, if you are a student of Indigenous Studies, it is an expected requirement to use accurate terminology and to understand the ins and outs of potential complexities. While this may be challenging, it is necessary and only challenging when one consider the pre-existing assumptions that European culture (British-Australian, British-New Zealand or Anglo-American, and so on) is the 'norm', the centre, and any deviation from its ways of knowing (epistemologies) is strange or difficult. Learning the varieties and complexities of names for the many cultural-language groups in Australia, for example, is no easier for an Aboriginal person just because he/she has command of his/her own language. Similarly, learning mastery of the different tribal names and their various synonyms is no less complex for an American Indian person in the United States just because the individual has knowledge of his/her own tribal nation. What might be different, of course, for the Indigenous person is the willingness to learn about different cultural groups' names, because the individual understands the importance of naming and the downside of being too easily grouped together; or the failure, altogether, to use accurate names.

If becoming a master of this particular academic subject were not enough on its own, a second - and not insignificant - reason to acquire greater facility with accurate terminology is respect. Using the appropriate names and accurate terms are fundamentally about recognising the impact of names on individuals and communities. If you are learning from and about another group and its histories - intellectual, creative, spiritual, political, psychological, physical, and otherwise - how much trust can you afford to squander, how much ill-will are you willing to spread? Imagine if someone always referred to you incorrectly or by the wrong name. After some time - perhaps after even correcting this person - you might begin to infer other meanings and messages attached to their lack of interest or concern: your name doesn't matter, you 
don't matter, and I can't be bothered to learn or care about you.

\section{References}

Alexie, S. (2000). One stick song. Brooklyn: Hanging Loose Press.

Attwood, B., \& Markus, A. (1997). The 1967 Referendum, or when Aborigines didn't get the vote. Canberra, Australia: Aboriginal Studies Press.

Augoustinos, M., Tuffin, K., \& Rapley, M. (1999). Genocide or a failure to gel? Racism, history and nationalism in Australian talk. Discourse and Society, 10(3), 351-378.

Augoustinos, M., Tuffin, K., \& Sale, L. (1999). Race talk. Australian Journal of Psychology, 51(2), 90-97.

Bedggood, J. (1997). Pakeha ethnicity? Sites, 35, 81-100.

Berglund, J. (2006). Cannibal fictions: American Explorations of Colonialism, Race, Sexuality, and Gender. Madison: University of Wisconsin Press.

Berglund, J. (2010). Sherman Alexie: A collection of critical essays. Salt Lake City, UT: University of Utah Press.

Berglund, J. (2013). Refusing nostalgia: Three Indigenous filmmakers' negotiations of identity. In M. Harris, M. Nakata, \& B. Carlson (Eds.), The politics of identity: Emerging Indigeneity (pp. 105-208). Sydney, Australia: University of Technology Sydney E-Press.

Bodkin-Andrews, G., \& Carlson, B. (2013). Racism, Aboriginal and Torres Strait Islander Identities, and higher education: reviewing the burden of epistemological and other racisms. In R. Craven \& J. Mooney (Eds.), Seeding success in Indigenous Australian Higher Education (Diversity in Higher Education, vol. 14, pp. 29-54). Bingley, UK: Emerald Group Publishing Limited.

Bolt, A. (2009, April 15). White is the new black. Herald Sun. Retrieved from http://blogs.news.com.au/ heraldsun/andrewbolt/index.php/heraldsun/ comments/column_white_is_the_new_black

Bolt, A. (2014, January 29). I am, you are, we are Australian. Herald Sun. Retrieved from http://www.heraldsun.com. au/news/opinion/i-am-you-are-we-are-australian/storyfnioffxg-1226813342744

Bran Nue Dae. (2009). [DVD]. Rachel Perkins (Director). Australia: Roadshow Home Entertainment.

Bureau of Indian Affairs. (n.d.). Why Indian Tribes exist today in the United States. Retrieved from www.bia.gov/ FAQs/index.htm

Callister, P. (2004). Seeking an ethnic identity: Is 'New Zealander' a valid ethnic group? Callister \& Associates. Retrieved from http://www.callister.co.nz/nzethnicgroup.pdf

Cameron, D. (1985). Feminism and linguistic theory. Basingstoke and London: MacMillan.

Carlson, B. (2011). The politics of identity: Who counts as Aboriginal today? (Unpublished $\mathrm{PhD}$ thesis). University of New South Wales, Sydney, Australia.

Coates, K. (2004). A global history of Indigenous peoples: Struggle and survival. Houndmills: Palgrave Macmillan.
Cooper, G.S. (1851). Journal of an expedition overland from Auckland to Taranaki by way of Rotorua, Taupo, and the West Coast undertaken in the Summer of 1849-50 by his Excellency the Governor-in-Chief of New Zealand. Auckland, New Zealand: Williamson and Wilson.

Dillon, A. (2012). Indigenous identity distracts from the real issues. The Drum. ABC. Retrieved from http://www.abc.net.au/unleashed/3915412.html

di Leonardo, M. (1984). The varieties of ethnic experience. Ithaca, NY: Cornell University Press.

Fleras, A., \& Spoonley, P. (1999). Recalling Aotearoa: Indigenous politics and ethnic relations in New Zealand. Auckland, New Zealand: Oxford University Press.

Greenland, H. (1991). Māori ethnicity as ideology. In P. Spoonley, P.D. Pearson, \& C. Macpherson (Eds.), Nga Take: Ethnic relations and racism in Aotearoa/New Zealand (pp. 90-107). Palmerston North, New Zealand: Dunmore Press.

Haslanger, S. (1995). Ontology and social construction. Philosophical Topics, 23(2), 95-125.

Harris, M., Carlson, B., \& Poata-Smith, E. (2013). Indigenous identities and the politics of authenticity. In M. Harris, M. Nakata \& B. Carlson (Eds.), The politics of identity: Emerging Indigeneity (pp. 1-9). Sydney, NSW: University of Technology Sydney E-Press.

Kelea Kelly, A. (Dir). (2009). Noho Hewa: The unjust occupation of Hawaii. Kailua, Hawaii: Kuleana Works Production.

Kearney, A. (2013). Emerging ethnicities and instrumental identities in Australia and Brazil. In M. Harris, M. Nakata, \& B. Carlson (Eds.), The politics of identity: Emerging Indigeneity (pp. 105-208). Sydney, NSW: University of Technology Sydney E-Press.

Liddle, C. (2014). Why I prefer the term 'black'. Daily Life. February 27. Retrieved from http://www.dailylife.com.au/ life-and-love/real-life/why-i-prefer-the-term-black20140224-33cte.html

Loomis, I. (2009). The Akaka bill. No Ka 'Oi/Maui Magazine, July-August. Retrieved from www.mauimagazine.net

MacKinnon, C. (1989). Toward a feminist theory of the State. Cambridge, MA: Harvard University Press.

MacKinnon, C. (1993). Only words. Cambridge, MA: Harvard University Press.

McKinnon, M. (2013). Place names - Māori and Pākehā names. Te Ara - the Encyclopaedia of New Zealand. Retrieved from http://www.TeAra.govt.nz/en/ place-names/page-7

McGloin, C. \& Carlson, B. (2013). Indigenous Studies and the politics of language. Journal of University Teaching and Learning Practice, 10(1). Retrieved from http://ro.uow.edu.au/jutlp/vol10/iss1/3/

McLintock, A.H. (Ed.) (1966). An encyclopaedia of New Zealand. Wellington, New Zealand: Government Printer.

Melbourne, H. (Ed). Māori sovereignty: The Māori perspective. Auckland, New Zealand: Hodder Moa Beckett.

Merlan, F. (2009). Indigeneity: global and local. Current Anthropology, 50(3). Retrieved from http://archanth.anu. 
edu.au/sites/default/files/documents/merlan_capaper .pdf

Moulton, J. (1981a). The myth of the neutral 'man'. In M. Vetterling-Braggin (Ed.): Sexist language (pp. 100115). Totowa, NJ: Littlefield and Adams.

Moulton, J. (1981b). Sex and reference. In M. VetterlingBraggin (Ed.), Sexist language (pp. 183-193). Totowa, NJ: Littlefield and Adams.

Nakata, M. (2013a). Identity politics: Who counts as Indigenous? In M. Harris, M. Nakata, \& B. Carlson (Eds.), The politics of identity: Emerging Indigeneity (pp. 125-146). Sydney, Australia: University of Technology Sydney EPress.

Nakata, M. (2013b). The rights and blights of the politics in Indigenous higher education. Anthropological Forum: A Journal of Social Anthropology and Comparative Sociology, 23(10), 289-303.

Neville, A.O. (1947). Australia's coloured minority: Its place in the community. Sydney, Australa: Currawong Publishing Company.

New Zealand Geographic Board (Nga Pou Taunaha o Aotearoa) Act. (2008). Public Act, Date of Assent 22 May 2008. Retrieved from http://www.legislation.govt.nz/ act/public/2008/0030/latest/DLM1065412.html

Niezen, R. (2003). The origins of Indigenism: Human rights and the politics of identity. Berkley: University of California Press.

Pearson, D., \& Sissons, J. (1997). Pakeha and never Pakeha. Sites, 35, 64-80.

Poata-Smith, E. (2013). Emergent identities: The changing contours of Indigenous identities in Aotearoa/New Zealand. In M. Harris, M. Nakata, \& B. Carlson (Eds.), The politics of identity: Emerging Indigeneity (pp. 2659). Sydney, Australia: University of Technology Sydney E-Press.

Ramsey, A. (2008). 'Weasel words won't hide monstrous shame'. Sydney Morning Herald. February 2,
2008. Retrieved from http://www.smh.com.au/news/ opinion/weasel-words-wont-hide-monstrous-shame/ 2008/02/01/1201801034773.html

Rangihau, J. (1992). Being Māori. In M. King (Ed.), Te Ao Hurihuri: The world moves on: Aspects of Māoritanga (pp. 183-190). Auckland, New Zealand: Reed.

Ransome, P. (2010). Social theory for beginners. Bristol, UK: Policy Press.

Rabbit Proof Fence. (2002). [DVD]. Phillip Noyce (Director). Rumbalara Films.

Roderick, E. (Ed.). (2008). Do Alaska Natives get free medical care (and other frequently asked questions about Alaska Native issues and culture. Anchorage, AK: University of Alaska Anchorage \& Alaska Pacific University.

Sissons, J. (2005). First Peoples: Indigenous cultures and their futures. London: Reaktion Books.

Smith, L. (1999). Decolonizing methodologies: Research and Indigenous peoples. London: Zen Books.

Spender, D. (1985). Man made language (2nd ed). New York, NY: Routledge.

Te Taura Whiri i te Reo Māori/Māori Language Commission. (2012). Guidelines for Māori Language Orthography. Retrieved from, www.tetaurawhiri.govt.nz

Treuer, A. (2012). Everything you wanted to know about Indians but were afraid to ask. St Paul: Borealis Books.

Vizenor, G. (1999). Manifest manners: Narratives on postindian Survivance. Lincoln, NE: University of Nebraska Press.

Wetherell, M., \& Potter, J. (1992). Mapping the language of racism: Discourse and the Legitimation of Exploitation. New York, NY: Columbia University Press.

William, H.A. (1992). Dictionary of the Mãori language (7th rev ed). Wellington, New Zealand: GP Publications.

Williams, H.W. (1971). A dictionary of the Māori language (7th ed.) Wellington, New Zealand: Government Printer.

Yellow Bird, M. (1999). What we want to be called. American Indian Quarterly, 23(2), 1-21. 


\section{About the Authors}

All four authors are part of an internationalised curriculum project to develop an Indigenous Studies subject that will explore critical issues in contemporary global Indigeneity. The subject will be taught at both the University of Wollongong and Northern Arizona University.

Bronwyn Carlson is a Senior Lecturer in the Indigenous Studies Unit, Faculty of Law, Humanities and Arts at the University of Wollongong. Bronwyn's research focuses on a number of interrelated themes, including the politics of Indigenous identity, with particular interest in what it means to identify as an Aboriginal person today focusing on what constitutes and is constitutive of Aboriginal identity in contemporary times. She was the first Indigenous person at UOW to be granted an Australian Research Council, Indigenous Discovery Grant. Her research project focuses is on how Aboriginal people represent and negotiate identity issues in the online space, more specifically in Facebook. Bronwyn is also one of the conveners of The Forum for Indigenous Research Excellence (FIRE) at the University of Wollongong.

Jeff Berglund is a Professor of English at Northern Arizona University where he is a President's Distinguished Teaching Fellow and affiliate faculty with Ethnic Studies and Applied Indigenous Studies. He is the author of articles on the Navajo punk band, Blackfire, poet Simon Ortiz (Acoma Pueblo), poet Esther Belin (Navajo), and the pedagogy of American Indian literature. He is the editor and contributor of essays to Sherman Alexie: A Collection of Critical Essays (Utah University Press, 2010) as well as the author of Cannibal Fictions: American Explorations of Colonialism, Race, Gender, and Sexuality (Wisconsin University Press, 2006). His newest work in progress is Indigenous Pop: Contemporary Native American Music of the 20th Century (University of Arizona Press).

Michelle Harris is an Associate Professor and Coordinator of the Graduate Program in the Department of Sociology and Social Work at Northern Arizona University. Her scholarly writings have focused on several areas, including acculturation and stress among immigrant Americans, how racial discrimination affects the mental health and wellbeing of Blacks in the United States, and the effects of sociodemographic factors and stress on the mental health of Jamaican adults. She has also published in the area of critical race theory. She envisioned and convened the first Working Group on Emergent Identities (2009) when her research interest shifted to issues of identity construction and performance among Indigenous Peoples around the world.

Evan Te Ahu Poata-Smith (Te Rarawa, Ngati Kahu) is the Discipline Leader of Indigenous Studies at the University of Wollongong. Prior to this he taught at the Auckland University of Technology and the University of Canterbury. More recently, he was a Fulbright Scholar-in-Residence at Northern Arizona University where he taught in the Applied Indigenous Studies and Sociology programmes. His research focuses on Māori political and social change. $\mathrm{He}$ is also one of the conveners of The Forum for Indigenous Research Excellence (FIRE) at the University of Wollongong. 